In his history of Saskatchewan, John Hawkes had the following account: "We cannot say when the pugnacious and voracious English sparrow first made his appearance in the Territories. We first saw him in May, 1900. We were sitting outside the hotel at Carnduff on the American boundary, and opposite were four grain elevators. Noticing some birds I said to a fellow loafer, 'Those look to me like English sparrows.' 'They are,' he said, 'they came here last fall and took possession of that elevator, and turned the grey birds out. They go into all the other elevators, but they won't let any grey bird come into theirs. They go from town to town but I think this is as far as they have got on this line yet'."'1

1HAWKES, J. 1924. Wildlife (Vol. 2, Chapter 91, pp. 899-907) in: The Story of Saskatchewan and its People. S. J. Clark Publishing Co., Regina.

2 HOUSTON, C. S. 1978. Arrival of the House Sparrow on the prairies. Blue Jay 36:99-102.

3SETON, E.T. 1909. Fauna of Manitoba Mammals and Birds (pp. 183-227) in: A Handbook to Winnipeg and the Province of Manitoba. Prepared for the 79th annual meeting of the British Association for the Advancement of Science, Winnipeg.

\section{MERLINS BREEDING AT BRANDON, MANITOBA}

MAMIE MCCOWAN, 1415 - 8th Street, Brandon, Manitoba, R7A $3 Z 6$.

In the March 1978 issue of Blue Jay (vol. 36, no. 1) there is an article entitled "Merlins Wintering and Breeding at Brandon, Manitoba".
This report included a 1977 nestin in Brandon Fair Grounds.

In 1978 a pair of Merlins nested i the Brandon Fair Grounds and raise five young. The first report in 1978 from a qualified observer, was of tw Merlins seen in February in the 197 nest area, and they were observe there in following months by severa people.

On 1 July, Hazel Patmore spotted the nest in a tall spruce tree, about $a$ metre from the tip. At that time she and I saw three fluffy young birds one in the nest and two on branches near the nest. The parent birds seemed to keep watch from cotton wood trees to the west and one would sometimes fly over our heads screaming when we were near the nest tree. Earlier that day Hazel had seen a Merlin in a cottonwood with a small bird, which it was plucking. On 3 July, she saw four young birds in the nest tree. Observations on 10 July were of young Merlins in nearby trees. On 13 July, I saw five Merlins that I took to be young birds. They were flying low over an open grassy area southwest of the nest site, from crossbars of power poles, and would often fly up into trees in an adjacent park. They did not appear to be excited by my presence, unlike the usual behavior of a parent bird. I have a note of two of the young Merlins perching close together and picking at each other. My last summer record is of two birds seen on 23 July.

On 15 September, I heard a Merlin in the Fair Grounds, and have the following subsequent reports of a Merlin being seen and/or heard in the Fair Grounds or in Brandon Cemetery, which is approximately half a kilometre south: 22 September, 6 October, 3 November, 15, 24 (a female), and 25 December. 